RESEARCH NOTE

\title{
FILM AS RESEARCH METHOD IN AFRICAN POLITICS AND \\ INTERNATIONAL RELATIONS: \\ READING AND WRITING HIV/AIDS IN TANZANIA
}

\author{
SOPHIE HARMAN*
}

\begin{abstract}
This research note reflects on the use of film as a method in researching politics and international relations in African countries. It is based on the experiences of producing a feature length drama about the everyday risk of HIV/AIDS using real people and their stories in Tanzania. The intent of the film, Pili, is to challenge international aesthetics of HIV/AIDS in film and how people understand the complexities and structural politics of disease. It is argued that the film itself is not the only outcome or contribution to knowledge. The external narrative or process of how the film was made, the method of doing, also produces new ways of thinking about ethics, collaboration and navigating the state in conducting research. The research note makes this argument by first reflecting on the origins and debates of visual method, and then exploring what film as a research method reveals about structure and agency, research collaboration, ethics and the state.
\end{abstract}

THE FEATURE LENGTH DRAMA PILI is based on the stories of women living with HIV/AIDS from the Pwani region of Tanzania. The film uses real people rather than actors, and real locations in which to stage the drama. Of the main cast, 65 percent are HIV positive. The intent of Pili is that the internal subject matter will challenge international aesthetics of HIV/AIDS in film and how people understand the complexities and politics of disease. In engaging with debates on visual method and the practicalities of film-making, the film itself is not the only outcome or contribution to knowledge: it is the external narrative or process of how the film was made - the method of doing - that produces new ways of thinking not only about HIV/AIDS but African politics and method in International Relations. The production of a film that uses real people and their stories is a form of ethnographic research requiring sustained relationships with research participants and the community in which it is set; new

\footnotetext{
*Sophie Harman (s.harman@ qmul.ac.uk) is a Reader in the School of Politics and International Relations, Queen Mary University of London. This project is funded by an AXA Insurance Outlook Grant and a Queen Mary University of London Innovation Fund grant. Thanks to the editors, two anonymous reviewers, Peter Brett and Clive Gabay for their insight and useful input, feedback, and reviews on earlier drafts.
} 
forms of engagement with the different parts of the Tanzanian state; and collaboration with non-academics from artistic rather than social science backgrounds. The research note explores these issues and makes the argument that the process of making a film is as revealing as the content of the film itself. It does this by reflecting on the origins and debates on visual method and African cinema, and then discussing what film as a research method reveals about questions of representing structure and agency in International Relations, research collaboration, ethics, and the state.

Why use film as a research tool?

The use of film as a research tool is a common method in the fields of Anthropology and Sociology, especially in Visual Anthropology and Visual Sociology. Such sub-fields have articulated the different uses of film as method from the popular 'reading' of film to the 'writing' (production) of film. The embeddedness of such methods is evident in the specialized awards for visual method, academic journals, and postgraduate degree programmes. ${ }^{1}$ Since 2000, other disciplines in social science have come to recognize the utility of film. For example, according to Jessica Jacobs, Geography integrates aspects of visual method (e.g. cartography), yet has only developed a more critical engagement with film as method in the last fifteen years. ${ }^{2}$ Greater use of both reading and writing of film within the wider social sciences has been in part a reaction to the changing use and technologies of image and aesthetics in teaching and research. Accessible and personalized technologies have facilitated the use of images in how people communicate and make sense of themselves and the world around them. This changing social phenomenon has led social researchers to reappraise and consider visual methods and adopt what Michael Shapiro refers to as 'trans-disciplinary method' across the arts, humanities, and social sciences. ${ }^{3}$

In the field of International Relations, scholars have noted 'the aesthetic turn' in research methods since $2000 .{ }^{4}$ Underpinning this 'aesthetic turn' is a commitment to use aesthetics and

\footnotetext{
${ }^{1}$ See for example Visual Anthropology, Visual Studies, the International Festival of Ethnographic Film, and UK research and teaching hubs in visual methods such as Visual Sociology Goldsmiths and the Granada Centre for Visual Anthropology, University of Manchester.

2 Jessica Jacobs, 'Visualizing the visceral: Using film to research the ineffable', Area (2015), DOI: 10.1111 /area.12198.

${ }^{3}$ Michael Shapiro, Studies in trans-disciplinary method: After the aesthetic turn (Routledge, London, 2013).

${ }^{4}$ Roland Bleiker, 'The aesthetic turn in international political theory', Millennium 30, 3 (2009), pp. 509-33; Roland Bleiker, Aesthetics and world politics (Palgrave Macmillan, London, 2009); Shapiro, Studies in transdisciplinary method.
} 
an assemblage of new, critical research methods and ideas to address complex world problems. ${ }^{5}$ Such assemblage recognizes the utility of visual method and 'trans-disciplinary method' as a critical encounter to rupture or discombobulate how we see and understand space, security and people in the world. ${ }^{6}$ Film as a research tool has principally been used to read film narratives, particularly in the context of post 9/11 US security films. ${ }^{7}$ A small number of scholars have produced short films on a range of subjects from engaging issues of US nationality and identity post $9 / 11$, diasporic communities, and Chinese toilets. ${ }^{8}$ The underlying argument for the use of visual methods such as film in the field of International Relations is that aesthetics can represent, imagine and challenge established structures of power and allow for new ways of seeing and thinking about international studies.

The disruptive use of aesthetics to challenge how we see space, security, and people chimes with the origins of African 'auteur' cinema as a visual method of decolonizing Africa's position in the international. ${ }^{9}$ The use of film as a challenge and disruption to aesthetic representations of Africa in the world has its origins in the formation of the Federation Panafricaine des Cineastes (FEPACI), a pan-African movement set up to create African films produced in and by Africans, national associations of film-makers, and the establishment of perhaps the most famous international film festival on the continent, the Panafrican Film and Television Festival

\footnotetext{
${ }^{5}$ Roland Bleiker, 'Art after 9/11', Alternatives: Global, Local, Political 31, 1 (2006) pp. 77-99; Roland Bleiker, Pluralist methods for visual global politics', Millennium 43, 3 (2015) pp. 872-890; Claudia Aradau and Jef Huysmans, 'Critical methods in international relations: The politics of technique, devices and acts', European Journal of International Relations 20, 3 (2014) pp. 596-619.

${ }^{6}$ Louise Amoore, and Alexandra Hall, 'Border theatre: On the arts of security and resistance', Cultural Geographies 17, 3 (2010) pp. 299-319; Alan Ingram, 'Making geopolitics otherwise: Artistic interventions in global political space', Geographical Journal 177, 3 (2011) pp. 218-222; Vivienne Jabri, 'Shock and awe: Power and the resistance of art', Millennium 34, 3 (2006), pp. 819-839; Debbie Lisle, 'Benevolent patriotism: Art, dissent and the American effect', Security Dialogue 38, 2 (2007), pp. 233-250; Michael Shapiro, Cinematic politics (Routledge, London, 2009); Shapiro, Studies in trans-disciplinary method.

${ }^{7}$ See for example Matt Davies, 'The aesthetics of the financial crisis: Work, culture, and politics', Alternatives: Global, Local, Political 37, 4 (2012), pp. 317-330; Shapiro, Cinematic politics; Andreas Behnke, 'The reenchantment of war in popular culture,' Millennium 34, 3 (2006), pp. 937-949.

${ }^{8}$ Elena Barabantseva and Andy Lawrence, 'Encountering vulnerabilities through "film-making for fieldwork", Millennium 43, 3 (2015), pp. 911-930; Cynthia Weber, Imagining America at war: Morality, politics and film (Routledge, London, 2006); Cynthia Weber, 'I am an American': Filming the fear of difference (Chicago University Press, Chicago, 2010); William Callahan, 'Toilet adventures', LSE Research Festival 2015, The London School of Economics and Political Science; James Der Derian, 'Now we are all avatars', Millennium 29, 1 (2010), pp. 181-186.

${ }^{9}$ Some African film critics and scholars note a distinction between 'auteur' African film, films that are shown in video parlours and eligible for entry to film festivals, and the popular African film exemplified by the Nigerian Nollywood industry and the Tanzanian Bongo Film industry that are African-financed and watched throughout Africa and the world. The distinction between the two in many respects can be one of snobbery, where 'auteur' cinema seeks 'to decolonize the minds of African audiences' and Nollywood which advocates of 'auteur' cinema see as a setback to African consciousness and stereotypes for its engagement with conspicuous consumption and witchcraft. See Matthias Krings and Onookane Okome (eds), Global Nollywood: The transnational dimensions of an African video film industry (Indiana University Press, Bloomington, 2013), p. 2.
} 
of Ouagoudougou (FESPACO). ${ }^{10}$ The 1975 Algiers Charter on African film consolidated this growing movement to recognize that film had an essential role in education and consciousness raising on the continent. ${ }^{11}$ FEPACI and the Algiers Charter established the foundations on which to shift the origins of African Cinema from a tool of colonial powers 'civilizing' and 'educational' missions to that of post-colonial statehood. ${ }^{12}$

However, the degree to which film has been a tool of decolonization has been mixed. After independence, a number of West African governments such as Ghana, Nigeria and Burkina Faso did invest in the production of film. Kwame Nkrumah, for example, 'built the most sophisticated infrastructure of film production in Africa. ${ }^{13}$ But this was the exception rather than the rule, as most governments prioritized other aspects of state-building. Until the 1990s and the rapid development of global 'Nollywood' in Nigeria and the much smaller 'Swahiliwood' in Tanzania, the majority of African films were financed, co-produced, and edited by European and North American donors. ${ }^{14}$ Nollywood was a turning point in which African film was fully African-financed with popular worldwide distribution. ${ }^{15}$

Film as a tool for research, education and consciousness raising is embedded within social methods and the politics of Africa. However, the use of film as a research method has in turn raised a set of important questions with regard to the role of the researcher, interpretation, transparency and research ethics. ${ }^{16}$ Principle among these questions is what the film is about or can be interpreted to be about: the subject and content of the film (internal narrative) or who made the film and under what circumstances (external narrative). ${ }^{17}$ David Lewis and colleagues argue that most films about development are not about the subject matter or the main characters, but are about westerners trying to understand their own role in the development process. ${ }^{18}$ This question chimes with debates on representations of Africa and Achille Mbembe's argument that

\footnotetext{
${ }^{10}$ Manthia Diawara, African cinema: Politics and culture (Indiana University, Bloomington, 1992).

${ }^{11}$ Francoise Pfaff, Introduction,' in Francoise Pfaff (ed.), Focus on African films, (Bloomington: Indiana University Press, 2004); Melissa Thackway, Africa shoots back: Alternative perspectives in sub-Saharan Francophone African film (James Currey, Oxford, 2003).

${ }^{12}$ Diawara, African cinema; Josef Gugler, African film: Re-imagining a continent (James Currey, Oxford, 2003); Mbye Cham, 'Film and history in Africa: A critical survey of current trends and tendencies', in Pfaff, Focus on African films, pp. 48-68.

${ }^{13}$ Diawara, African cinema, p. 6.

${ }^{14}$ Diawara, African cinema; Thackway, Africa shoots back.

${ }^{15}$ Krings and Okome, Global Nollywood.

${ }^{16}$ Marcus Banks, Visual methods in social research (Sage Publications, London, 2001).

${ }^{17}$ Banks, Visual methods in social research.

${ }^{18}$ David Lewis et al, 'The project of development: Cinematic representation as an(other) source of authoritative knowledge', in David Lewis, Dennis Rodgers, and Michael Woolcock (eds), Popular representations of development: Insights from novels, film, television and social media (Routledge, Abingdon, 2014), pp. 113-130, p. 125 .
} 
Africa serves as a metaphor through which the West can make sense of its own identity. ${ }^{19}$ For a European researcher/film producer, such questions are unavoidable and underpin the research process of making a film. Acknowledgment of such a relationship is fundamental to the reading of the external narrative of a film and produces an additional set of research findings with regard to the power relations between producer, subject and the state.

This research note argues that the external narrative of film - who and how it was made reveals more than the internal narrative - the subject and content - of the film itself. The intent of the internal narrative is to use film as a visual method to disrupt how HIV/AIDS is understood in the international, challenge the aesthetic of HIV/AIDS in film as the 'skinny white male,' and give voice and space for those often unseen, assumed or disregarded in international relations but who make up the majority of people living with HIV/AIDS in the world. ${ }^{20}$ Film was chosen as a research method to allow women living in rural Tanzania to tell their own stories to the biggest audience possible. Film allows an exploration of the internal narrative of people's lives and their intersection with global economies and health strategies through storytelling, their own words, and actions. The decision to make a drama rather than a documentary was to allow the actors to be free to express themselves through characters rather than directly playing out their own lives. Even though the story of the film is based on their lives, in dramatizing the story the actors did not have to bear public responsibility or exposure for some of the more difficult choices the characters make. Other artistic mediums such as painting, photography, and oral histories were considered, but film is the biggest medium for making women who tend to be conspicuously invisible in global health and international relations visible. The internal narrative tells one story about the aesthetic representation of HIV/AIDS and the lives of the women in the film; however, it is the external narrative of writing a film that contributes to understanding research collaboration, ethics, and structure and agency in international relations and debate on the African state. The findings and reflections outlined here contribute to the call in the field of International Relations for methodological pluralism by showing how visual methods and the process of doing rather than asking or observing can open up new findings and points of inquiry.

\footnotetext{
${ }^{19}$ Achille Mbembe, On the postcolony (University of California Press, Berkeley, 2001); Julia Gallagher, 'Healing the scar? Idealizing Britain in Africa, 1997-2007', African Affairs 108, 432 (2009), pp. 435-451; Toussaint Nothias, "Rising," "hopeful," "new": Visualizing Africa in the age of globalization,' Visual Communication 13, 3 (2014), pp. 323-339.

${ }^{20}$ UNAIDS, Factsheet; see also Sophie Harman, 'The feminisation of HIV/AIDS', Globalizations 8, 2 (2011), pp. 213-228.
} 
A common challenge with research on African politics is the need to balance a focus on African agency, attention to African states, societies, individuals, governments as actors rather than acted upon, against the structural limitations or opportunities that frame and respond to such agency. ${ }^{21}$ Film that focuses on content and themes of international development and politics have been criticized for focusing on agency and individuals rather than addressing the wider structural determinants of poverty. ${ }^{22}$ Capturing and explaining structural drivers of poverty and inequality is a challenge for story-telling, as dramatic films tend to follow individual narratives. There is a clear reason for this: people are interested in the stories and dramas of people's lives and personalizing explanations of seemingly dry issues - how a woman accesses healthcare makes such issues a lived experience that may (or may not) evoke a response to what the viewer sees. Stories require protagonists to drive the drama or communicate the themes that are explored. However, the use of individual narratives when exploring issues of international development such as HIV/AIDS and rural poverty opens such stories to the instrumentalist trap. The instrumentalist trap suggests that regardless of the structures of inequality that limit the everyday choices and experiences of the lives of women living in rural Pwani, these women are resilient in the face of such inequalities and such resilience will allow them to pull themselves and their families out of poverty. This instrumentalist trap is heavily gendered within international policy practice. $^{23}$

The challenge of making a drama rather than a documentary is therefore to capture this urgency of the everyday while explaining its relationship to structural drivers of poverty and the international. Women living in rural Pwani do not sit around talking about the structural limitations of the postcolonial Tanzanian state or the constant reforms of the health system on account of different donor and international institutional priorities. These women do, however, have acute expectations and understanding of how these health systems and power structures

\footnotetext{
${ }^{21}$ I use the definition by William Brown and Sophie Harman, 'African agency in international politics', in William Brown and Sophie Harman (eds), African agency in international politics (Routledge, London, 2013).

${ }^{22}$ Parker, 'The project of development', p. 125.

${ }^{23}$ Shahra Razavi, 'World development report 2012: Gender equality and development - a commentary', Development and Change, 43, 1 (2012): pp. 423-437; Penny Griffin, 'The World Bank', New Political Economy, 11, 4 (2006), pp. 571-81; Lucy Ferguson and Sophie Harman, 'Gender and infrastructure in the World Bank,' Development Policy Review 33, 5 (2015), pp. 653-671; Sylvia Chant, 'Rethinking the 'feminisation of poverty' in relation to gender aggregate indices', Journal of International Development, 7, 2 (2006), pp. 201-220.
} 
work in their community. The film is therefore structured in a way that captures this understanding and resistance or agency against these structures that these women exhibit.

The structures of poverty and development frame the drama and narrative of the film. The film is driven by the lead character Pili. The action of the film is how Pili encounters, bends, and jumps the structures of her everyday life. The film is arranged around three dominant structures of power. The first is the gendered structures in which Pili finds herself as a working single parent living with HIV. We see Pili balancing competing responsibilities of productive employment and social reproduction with her family and wider community. The burden of such responsibility has direct consequences for how she cares for herself and her health. The second structure of power is with regard to the state and the global politics of the health system. This structure relates to the everyday burden, boredom, and time used to access treatment for HIV and the stigma and shame that these can bring. The final power structure is that of the informal agrarian cash economy in which Pili works and her ambition for autonomy and ownership of her labour. This was a consistent theme among the women engaged in preparing the story of the film; most women engaged in the project stated their main ambition was to own a small business as a means of earning more money and sustaining themselves and their families. While the narrative of the film is driven by Pili, the cycles of inequality and how these structures permeate and reproduce themselves is represented by her and her social circle, specifically the character of Zuhura who closes the film. As a method of research, film not only explores these questions of agency but can demonstrate the intersection between African agency and the political, economic and social structures that constrain such agency.

\section{Collaboration and co-production of research}

Film opens up new ways of conducting research through trans-disciplinary collaboration and co-production of research with research participants. As the film's producer, I established the topic, research questions, and analytical frame of Pili, but worked with the research participants/cast and director to develop the content of the film, and with a crew of film-makers to develop the aesthetic of the film. Collaboration and co-production was important to the authenticity and quality of the film and for opening up new ways of engaging different actors in the research process; collaboration and co-production was fundamental to ensuring Pili was based on the stories of the women in the film. However, co-production also generates a series of practical issues that illustrate the difficulty of trans-disciplinary research. 
The story of the film is a piece of co-produced research between me, the director, and a group of women living in the Pwani region of Tanzania. As part of the pre-production, the director and I met with approximately 85 women in rural Pwani to hear their stories. These meetings involved initial group conversations, as this was the women's preference, and then one-on-one follow up conversations with the women who volunteered their story. The director and I then combined the common themes of each of the women's stories - their position as a 'left one, ${ }^{24}$ their work in the fields and aspiration to own a small business, motherhood, HIV status and health complications, kinship with micro-lending and peer-to-peer support groups - to make the main story of the film. The director and I co-wrote the story, and the director wrote the screenplay. The challenge of writing the overall story was not only reflecting these individual stories, but also how they could be presented in an engaging narrative that would make sense to both Swahili and non-Swahili speaking audiences. The challenge was also to represent their story without inserting my own bias or prejudices. For example, a big part of the film is whether the character can secure funding from the 'Vikoba' micro-lending group. I was reticent about the inclusion of such groups because of critiques around low-level debt and the sustainability of micro-lending. However, micro-lending played a prominent part in these women's lives, and they were positive about it; therefore, the 'Vikoba' group appears in the film.

To assess the authenticity of Pili, the story was tested and refined with smaller groups of women living with HIV/AIDS in Pwani. These women contributed regarding the finer practical details, such as how micro-lending worked in practice, and commented on the plausibility of the characters and what happens to Pili in the film. Feedback from the women consulted and the cast members endorsed the story, with one woman noting 'Pili is everywhere,' and a number of women clapping at the difficult parts of the story and stating 'it happens' at contentious points. When asked about the only part of the film that may be seen as less authentic - in one scene Pili takes a motorbike along the beach - the women agreed that it may not happen but that it would look good on film so keep it in. The screenplay of the film contained some dialogue that was essential for plot development; however, much of the content was improvised under direction. Making a film involved an extended ethnographic encounter with the women that allowed them to express themselves through their own stories, telling the stories of their character, and explaining the everyday political issues they encounter through drama. In this sense, the women were a combination of research participant, co-producer, and actor.

\footnotetext{
24 'A left one' was a phrase used by all the Tanzanian women engaged for the project. It is a label referred to a woman who has been left by her partner, often to bring up a child as a single parent.
} 
The women's stories corroborated existing research and generated new findings on the everyday risk of HIV/AIDS. A significant finding was how stigma remained an underlying problem in the local community, particularly self-stigma. Stigma has long been a concern of the international HIV/AIDS response, but there has been a general sense of progress in this area. If you ask people directly about stigma in an interview setting, they often suggest things were bad but they have got better. However, in asking women to share their stories and build a film narrative around them, it became clear that stigma and self-stigma were pertinent issues. Self-stigma led to some women proclaiming that they did not want to re-marry for fear of exposing a partner to HIV, and that they would rather seek out and pay for black market antiretroviral treatment than get it for free from the public clinics. The women explained they could now go to the police who would fine anyone who stigmatized them because of their status, but that also involved discussing their health in public. The use of film helped explore these issues, and the women became more open about the hidden consequences of self-stigma. The cast was drawn from the women who shared their stories with the director and I. All women were given the option of being in the film and to attend an acting workshop. Of those interested, casting was dependent on age, ability and their story. Many of the women who shared their stories were too old to play the lead character, but took on other roles. Some individuals had parts written specifically for them given their stories and presence in the community. None of the women had acting experience, but through workshops the director identified those who could act and/or take direction. The women cast in the film had direct input in the shaping of the characters and the story during production. The core cast of women helped to identify other women who would be good at playing specific roles, extras, and locations.

The production of Pili required a relatively small crew of producer, director, director of photography, camera assistant, sound recordist, two production assistants/interpreters, one interpreter/driver, and one driver. I was the only academic member of the crew. Half the crew were Tanzanian, and the other half were British. The 'above the line' members of the crew the producer, director and director of photography - were all from the UK; whereas, the 'below the line' members of the crew were Tanzanian. A number of Tanzanian production companies were consulted in pre-production planning to ensure a greater balance between above and below the line crew members. As film critic and historian Manthia Diawara has argued, coproductions of African films should be made up of African crew as they are cheaper, can help 
reach wider audiences, and make use of kit that may otherwise fall into disrepair. ${ }^{25}$ However, contrary to Diawara's argument, the cost of Tanzanian filmmakers was three to four times the cost of working with UK professionals. The cost was higher for both professional fees (including when weighted to consider travel costs for UK professionals) and kit (kit hire in the UK was both of better quality and cheaper). Therefore even though the intent was to have a crew that was predominantly Tanzanian the budget constraints meant using a relatively inexperienced crew from the UK was more affordable than established Tanzanian production companies.

Collaboration was based on a shared understanding of the intent of the project. First, the film seeks to create an immersive, social realist drama based on the lives of the women who would be acting in the film as a means of telling the story of the everyday risk of HIV/AIDS treatment and care. Diawara suggests African film falls into one of the following categories: social realist, colonial confrontation, and return to the source ${ }^{26}$ Pili draws directly on the history of African cinema by building on social realist styles of drama that have made rural women the main subject of the drama. ${ }^{27}$ Second, the film seeks a broad international audience, and all profits from the film would go back to the communities in which the film is based and the intent is to explore issues around HIV/AIDS. This basis for the collaboration was clearly shared by cast and crew, but problems still emerged around issues such as developing a common understanding that any of the main cast can walk off set at any point because of ethical obligations; different expectations of audience; what the budget can and cannot pay for; and the complex finance structures of university pay and procurement.

\section{The ethics of film as research method}

The film adhered to standard ethical principles and processes of the university sector: participant information sheets (provided in English and Swahili), signed consent forms, filmed explanations of the project, and the caveat that all participants could withdraw from the project at any point during the production. Anonymity for the research participants/cast was

\footnotetext{
${ }^{25}$ Diawara, African cinema.

${ }^{26}$ Ibid; Gugler, African film. Some Africa film scholars have extended Diawara's categories to include subgenres in anti-apartheid film in South Africa (see for example Mapontsula, Fools, and A dry white season), and label social realist films such as 'The exploited and neglected peasantry'. Social realism has also been popular in European film-making and the work of producers such as Michael Balcon, and directors such as Ken Loach, Mike Leigh, and Jean-Pierre and Luc Dardenne.

${ }^{27}$ Popular examples of this style La Vie est Belle, Visages de Femmes and Bouka.
} 
impossible, given their faces appear on the screen, they are listed as cast members in the credits of the film, and the intent of the film is to tell the stories of the women in their community. The issue of stigma was discussed with all the research participants/cast, the majority of whom stated they were open about their status and wanted to use the film to educate people and raise the profile of women living with HIV/AIDS.

Paying the women to participate was decided at the outset of the project: women would be giving up their time and forgoing other sources of temporary informal employment to work on the project for a five week period, so they should be paid for their labour. The problematic issue is not the ethics of whether to pay (although this was discussed at length with the ethics committee), but rather how much to pay so as not to coerce participation. Each woman was paid TSh10,000/US\$5.00 per day for their involvement in the project, which is above the poverty line and approximately four times higher than the average wage of the women involved. However, they would be working long days, sometimes away from home, and may have the extra cost of childcare arrangements. The lead actress/research participant was paid Tsh20,000/US\$10.00 per day so she could pay for someone to accompany her and look after her daughter when filming. All cast members received lunch and water everyday, as well as all meals and accommodation expenses when staying away from home.

The most prominent issue of money was managing expectations as to the long term benefits of participating in the film. Any profits from the film will go back to the community through established NGOs that helped with the production and through a 'Pili' fund. This fund will give money to education, health and small business opportunities for the women in the communities in which the film is set. The money will be managed by a group of women, of which half will be drawn from the film cast and half from outside of the film (so as to avoid accusations of bias). This group will assess applications, award grants, and provide me with annual updates as I help manage the fund. All the women in the film were aware of this. However, there is no guarantee that the film makes money; therefore, while the film will have an impact with regard to the stories told, once the shoot was finished the women returned to their everyday lives of working in the fields.

\section{A new method for understanding the Tanzanian state}

The practice of making something, in this case a film, and paying people for their time and work produced new insights into the functions of the Tanzanian state. The process of doing, 
rather than observing or asking, allows for first-hand experience of how things get done within the state at different levels of governance. Three incidents involved in the practice of making the film not only revealed how the state functions, but also elicited wider questions about depictions of Tanzanian and African statehood.

The first incident was the attempt to secure a film permit. The government of Tanzania does not want films to be made that challenge the state's reputation as having 'showcase status' among donors, ${ }^{28}$ reflect badly on the government, or address contentious issues. The state can control what stories are told from Tanzania by controlling the issuing of film permits. The issue of film permits are similar to those of attaining research permits to conduct research: ${ }^{29}$ on the one hand it is important to act in keeping with the rules of the state in which you are working, but on the other, states can use the issuing of permits to extract revenue and control or censor research and films that are made.

An application for a film permit to the Tanzanian High Commission in the UK was made in October 2015, and when that was approved, a full application was submitted to the Tanzanian Film Board via email and then in person in November 2015. This was an interesting time in Tanzanian politics. President John Magufuli was elected in November 2015 on a reformist mandate and had begun a series of high profile measures to limit state corruption, waste and poor performance. Magufuli publicly cut the budget for the parliament opening state dinner from TSh300million/ $\$ 150,000$ to TSh25million/ $\$ 12,500$; he banned first class travel for government trips for all except the very senior members of government; he suspended the commissioner of the Tanzania Revenue Authority over the loss of cargo containers worth Tsh80billion/\$40million; and began popping up in various Ministries and hospitals unannounced to question why people were not in work and why machinery was not working. ${ }^{30}$ Such gestures prompted popularity among both Tanzanians and Kenyans who thought their government could learn from Magufuli, as depicted by the social media hashtag \#whatwouldmagufulido. ${ }^{31}$

\footnotetext{
${ }^{28}$ Graham Harrison, The World Bank and Africa: The construction of governance states (Routledge, Abingdon, 2004), p. 39.

${ }^{29}$ A.F. Robertson, 'Doing research in Africa', African Affairs 84, 335 (1985), pp. 279-290, p. 284; Susan

Thomson, 'Whispering truth to power: The everyday resistance of Rwandan genocide peasants to post-genocide reconciliation', African Affairs 110, 440 (2011), pp. 439-456, p. 444.

${ }^{30}$ Allafrica.com, 'Behind Magufuli's political stunts', 18 January 2016,

<http://allafrica.com/stories/201601190736.html> (31 January 2016); Kieron Monks, 'John Magufuli, the nofrills President who declared war on waste.' $C N N$ (14 January 2016),

<http://edition.cnn.com/2016/01/14/africa/tanzania-president-john-magufuli/> (31 January 2016); BBC News,

'Tanzania's Magafuli scraps independence day celebration', 24 November 2015,

$<$ http://www.bbc.co.uk/news/world-africa-34909111> (31 January 2016).

31 <https://twitter.com/hashtag/whatwouldmagufulido> (31 January 2016).
} 
The election of Magufuli and his new style of politics meant the pre-production and production of the film, from November 2015 to March 2016, took place in a period of potential upheaval and unease for those working in government. Securing a film permit thus became caught between gatekeeping practices of controlling what stories are told in Tanzania and officials second-guessing the next move of the President. Once all documentation was submitted to them in October, the Film Board suggested attaining the permit would be a straightforward process. However, in November the Film Board suggested a letter of support was required from the Ministry of Health and Social Welfare. After submitting paperwork detailing the film synopsis, UK crew passport details and biographies, ethical considerations, and three days of sitting in the Ministry of Health and Social Welfare, the Director of Preventive Services provided a letter but noted two members of the Ministry would have to be present throughout the shoot and their full per diems and expenses paid by the project. After the letter was issued, the Chief Medical Officer emailed a list of requirements the film would have to meet to receive approval, the majority of which you would expect, but one requirement was that the Ministry would have a final veto over the final content of the film. ${ }^{32}$

Once the letter from the Ministry was secured, the Film Board noted that as the word 'research' appeared twice in the synopsis the application had to be referred to the government research agency COSTECH. By the end of November, the Film Board requested $\$ 1000$ be transferred to secure the permit. Once the money was transferred and in the account of the Director of Information Services, the Film Board stated that because the film included HIV/AIDS the

\footnotetext{
${ }^{32}$ Email correspondence with the Chief Medical Officer stated the film would require the following to gain approval:

1. Your correspondence to the Ministry of Health and Social Welfare (MoHSW) should be addressed to the Permanent Secretary (PS), MoHSW

2. The formal request letter to the MoHSW should be submitted by an appropriate and recognized authority of your institution (Queen Mary University of London), who should dully [sic] sign the letter

3. The request letter should also include:

a. Curriculum vitae of all those who will be involved in the filming

b. Copies of passports of all those who will be involved in the filming

c. Concept note/Synopsis

d. A list of all the equipment that will be used in the filming and or profile of the [sic]

4. Once points 1-3 above are met, the PS of MoHSW will then submit a recommendation to the Ministry of Information, Culture and Sports for a filming permit.

5. A copy of the filming permit has then to be submitted to the MoHSW so that a Clearance letter is given by the MoHSW subject to the following conditions being met:

a. The location(s) of the filming is made absolutely clear

b. That the filming will be supervised by the Health Promotion Education "Elimu ya Afya kwa Umma" Section of the MoHSW. A designated Officer will be attached to the work.

c. A consent form will be duly signed by all participants in the film

d. The film will be submitted to the MoHSW for a preview, editing and final approval before it is distributed, shown, or stored in any form

6. It is further strongly advised that actors are used in the film rather than real patients, in view of the stigma attached to the disease in our circumstances.
} 
project had to be referred to the National Institute for Medical Research (NIMR). The project and film do not involve medical research, and no one involved in the project has a clinical background or any experience in medical research. The Film Board were informed of this in writing, by colleagues in Tanzania, and by fixers engaged to help sort out the problem of the permit. By February 2016, one fixer deployed all their contacts to try and address the problem. The Film Board were firm in their need for NIMR to approve the project, but they had not formally notified NIMR of this. Once contact was made with NIMR, an additional $\$ 500$ was paid to submit the application to them together with five hard copies (the emailed versions were rejected) of a letter of introduction, a letter of support from the charity affiliated to the project, and a complete application form (most of which referred to clinical trials and was therefore not applicable to this project). As of July 2016, the government of Tanzania had received $\$ 2000$ for the project: $\$ 500$ for five business visas for the UK crew, $\$ 500$ for the NIMR application, and $\$ 1000$ for the Film Board, but no film permit was issued.

The film production proceeded without a formal permit. No permit presented two central risks for the project: first that the government could confiscate the kit on the understanding that filming was not authorized, and second that the safety and work of the cast and crew could be compromised. The risk of kit confiscation was addressed by the purchase of political risk insurance, but this was expensive and hard to attain as most political risk involves some form of violence in a high-risk country rather than a film kit in a peaceful country. Cast and crew safety was and remains the greater concern. The Tanzanian state has penalized citizens for participating in films such as Darwin's Nightmare, ${ }^{33}$ so the long term consequences and responsibility of the production team to the Tanzanian cast and crew is the more pressing and important issue to address as a researcher with an ethical obligation to research participants. Protection of the cast has been sought by involving local politicians in the area in which the film was made and establishing a support network between Tanzania and the UK.

The second incident was the case of attempted bribery by a translator working on the project, which showed that the greater risk to not having a formal film permit was to the crew rather than the cast. In the sixth and final week of the project, one Tanzanian translator on the project threatened the film production over a pay dispute. All Tanzanian crew members were paid an agreed fee and lunch; their contracts were clear in stating their pay did not include extra per diems or accommodation. Three days before the end of the shoot, one translator suggested this

\footnotetext{
${ }^{33}$ Xan Rice, 'Tanzania sees malice in Darwin's nightmare,' 17 August 2006, The Guardian, <http://www.theguardian.com/world/2006/aug/17/film.filmnews〉 (31 January 2016).
} 
was unfair, accused me of different treatment to crew members, and demanded per diems and accommodation fees for themselves and two other crew members. The translator threatened to inform the Film Board and immigration if I did not pay them what they wanted. ${ }^{34}$ On the final day of shooting, the crew member presented a breakdown of the amount claimed for accommodation. This breakdown included nights when the three crew members had stayed in their own homes, inflated costs, and one crew member claimed for one week already paid for by the project. After contesting this, I was publicly threatened and informed I would be driven to a cashpoint every day for my four remaining days in Tanzania to withdraw money, otherwise the translator would deliver on their threat. I withdrew cash on the first day. On the second day I agreed to meet the translator at 10:00, but left with the remaining crew members for Dar es Salaam at 7:00. On day 4, the UK crew passed through immigration and security at Julius Nyerere International Airport. Three policeman and the translator who had made the threat arrived in Departures (note the crew member was able to be air side of security) and detained the crew in the airport police room on the Tanzanian side of the airport. It took 45 minutes to be told what the issue was and that all crew members were free to leave except me, who had to return to Bagamoyo to face charges. Once the police outlined the charge - the translator was claiming an outstanding balance of TSh9million/ $\$ 4,500$ - I presented them with documentation proving all invoices had been paid, and multiple receipts and statements for additional payments. The airport police were satisfied with this evidence, and the UK crew were free to go. I have since instructed a Tanzanian lawyer to follow up with Bagamoyo police and according to their records no formal charges against me exist.

The third incident was the purchase of key props for the film. One prop was a car that had been involved in an accident. The Tanzanian crew members recommended that this could be organized through the traffic police, as damaged cars were common in the area. ${ }^{35}$ On first meeting, the police agreed to assist as long as the owner of one vehicle they had in mind agreed.

\footnotetext{
${ }^{34}$ All UK crew members had full business visas. Earlier in the shoot the same translator who was asking for more money told me that immigration officials in Bagamoyo were asking questions about the crew. I provided Bagamoyo immigration with copies of all UK crew passport details, business visas, and visa application details. After doing so I was requested to attend a meeting where local immigration told me the UK crew business visas were not business visas and that if I paid them $\$ 150$ per UK crew member everything would be fine. I did not pay them but left the office. It was clear that they had colluded with the same translator to gain extra funds from me.

${ }^{35}$ According to WHO estimates, Tanzania had 16, 211 road traffic accident fatalities in 2013, which was 32.9 per 100,000 of the population. This is a higher rate than neighbouring Kenya (29.1 per 100,000) and South Africa (25.1 per 100,000). Tanzania does not have laws on child restraints or use of mobile phone when driving but does have laws on speed limits, drink-driving, seatbelts, and helmets for motorcyclists <http://www.who.int/violence_injury_prevention/road_safety_status/2015/Country_profiles_combined_GSRRS 2015 2.pdf?ua=1> (31 May 2016).
} 
The project would have to pay for the pick-up truck and the per diem of two officers to accompany the car. On the second meeting, the police informed the crew that the owner of the car did not want it to be used but the police could assist if paid Tsh800,000/\$400. When asked if another car may be available, the police suggested the situation would most likely be the same; instead, the crew could pay the police and not have to complete any paperwork. This discussion took place at the side of a road, as police checked inter-city buses and street vendors sold cashews to passengers through the window. Once agreed the police stuck to their agreement and the car was delivered, accompanied and returned.

An initial reading of these three incidents would suggest that producing a film shows how making something in Tanzania requires substantial paperwork and money and is fraught with risk. It reflects the 'petty pilfering of funds' common to different aspects of the Tanzania state. ${ }^{36}$ One reading is that these incidents show evidence of the postcolonial neopatrimonial state: ${ }^{37} \mathrm{a}$ 'managerial bourgeoisie' that gate-keep to protect their own interests (the Film Board), government service as a means of securing extra money through per diems (Police, translator), job precariousness (Film Board), and a hierarchy within government (NIMR and the Ministry of Health and Social Welfare having greater influence than the Film Board). ${ }^{38}$ Much of the above corresponds with this depiction, but the neopatrimonial label lacks nuance. An alternative reading is that these three incidents raise questions as to the role of trust and more importantly, distrust, in how the Tanzanian state functions. Hazel S. Gray has analysed how intra-elite distrust within CCM undermines the ability to address corruption in Tanzania. ${ }^{39}$ Such analysis points to the levels of fragmentation and distrust among the elite in government, however the experience of making the film suggests that such distrust is not only among the elite but filters throughout different aspects of society. A common subtext to much of the discussion of government agencies in relation to Pili is they somehow did not trust what the project was about. This is in part perhaps because the paperwork highlighted how the film was a 'docudrama', which is not easy to categorize and led to confusion. However it was also in part because all paperwork was submitted directly without going through known fixers who seem

\footnotetext{
${ }^{36}$ Hazel S. Gray, 'The political economy of grand corruption in Tanzania', African Affairs, 114, 456 (2015), pp. $1-22$, p. 2.

${ }^{37}$ Crawford Young, The postcolonial state in Africa: Fifty years of independence, 1960-2010 (University of Wisconsin Press, London, 2012); William Tordoff, Government and politics in Africa (Palgrave Macmillan, Basingstoke, 1997).

${ }^{38}$ Richard L. Sklar, Corporate power in an African state: The political impact of multinational mining companies in Zambia (University of California Press, Berkeley, 1975); see also Jean-François Bayart, The state in Africa: The politics of the belly (Polity Press, Cambridge, 2009), p. 249.

${ }^{39}$ Gray, 'The political economy of grand corruption in Tanzania.'
} 
to legitimize applications to the Film Board. Submitting paperwork without knowing someone who acts as a legitimizing agent produces distrust. Once fixers were introduced to help assist with the process, they were informally told 'who is this girl?' 'what does she want?' in an attempt to both demonstrate hierarchy (repetitive use of 'girl') and lack of trust. Distrust emphasizes the need for short-term gain and self-protection that manifests itself through bribery, per diems, and bureaucracy as evidenced not only by my encounter with the police but also the translator. This distrust becomes self-reinforcing and exacerbated as resources decline. It is beyond the scope of this research note to explore this final reading in detail, but it begins to highlight the role of trust not only between party elites but throughout different aspects of government and society.

A final reading to be made from these incidents is the position of HIV/AIDS and people living with HIV/AIDS within Tanzania. The government reaction to the film could be read as an attempt to protect people living with HIV/AIDS from exposure or exploitation by a foreign film crew. This appeared to be the official position of the Ministry of Health and Social Welfare and NIMR. On one level, such actions discriminated against people living with HIV/AIDS by limiting their opportunity and choice to be in the film in ways people who were not HIV+ were not. The intent of the film was to positively discriminate in favour of people living with HIV in Tanzania so they could tell their stories. Excessive state protection led to negative discrimination. However, on another level, the actions of the state reflect a wider tendency to view HIV/AIDS as an exceptional health issue. Exceptionalism is related to stigma, behaviour, and celebrity, but it is also about the amount of money allocated to HIV/AIDS in global health that has resulted in the disease being instrumentalized by governments and civil society in different ways for material gain. This is not a new finding but corresponds with work on the markets developed around HIV/AIDS funding by community organizations. ${ }^{40}$ What is new about this is how entrenched HIV/AIDS as a means of material gain is within both the state and those communities engaged in making the film. This was evident at the government level with HIV/AIDS being the exceptional issue for referral and payment to other sectors of government beyond the Film Board. This was also evident at the community level with crew members using pay related to HIV/AIDS government per diems as a rationale for extra payment and justification of extortion practices. It was not the making of a film alone that suggested money; it was because the film was about HIV/AIDS that suggested a well-resourced project and thus an opportunity for extra income in a resource poor setting.

\footnotetext{
${ }^{40}$ Sophie Harman, The World Bank and HIV/AIDS: Setting a global agenda (Routledge, London, 2010).
} 


\section{Conclusion}

This research note has demonstrated that film as a research method not only seeks to make an impact on how people see or understand the everyday risk of HIV/AIDS, but also produces preliminary research findings on the Tanzanian state and how trans-disciplinary method in the field of International Relations works in practice. The use of film as a research method challenges how we think about the ethics of vulnerable populations (here, people living with HIV/AIDS) in research, representations of structure and agency, and the relationship between the researcher and the context in which they work. Practically, the research note has demonstrated how film is fraught with practical and ethical challenges. The production of a film requires complex engagement with the state and the subjects of research who occupy dual roles as research participants and collaborators. Trans-disciplinary collaboration necessitates a shared understanding of intent and interests that can be agreed in principle, but result in difficulties in practice. This can come at a cost of personal risk to the researcher and collaborators. A short conclusion would be to recommend that researchers using film as method commission a production company to make the film for them. This would reduce a number of the risks and difficulties associated with film production and remove the need for universities to act as commercial production companies. However, to do so would increase the cost of production and reduce the depth of experience and research findings generated by the ethnographic process of producing a film. As this research note has shown, much of the richness of using film as a research method is not in reading and writing the internal narrative of what the film is about, but reading the external narrative of how the film was made. To ignore this external reading is to ignore how films based in Africa can say as much about the filmmakers as the subject of the film and how they engage in the wider politics of the society and state in which they operate. It is this latter engagement that offers new perspectives, questions and ways of thinking about African politics and international relations. 